DOI: $10.15193 /$ zntj/2017/110/170

\author{
JOANNA GŁAZOWSKA, URSZULA STANKIEWICZ, \\ AGNIESZKA BARTOSZEK
}

\title{
ABSORPCJA, METABOLIZM I ROLA BIOLOGICZNA KWASÓW NUKLEINOWYCH OBECNYCH W ŻYWNOŚCI
}

\begin{abstract}
Streszczenie
Kwasy nukleinowe należą do niedocenianych składników żywności, szczególnie surowej lub nisko przetworzonej. W niniejszej publikacji skupiono się na omówieniu przemian, jakim podlegają kwasy nukleinowe w przewodzie pokarmowym człowieka, procesie absorpcji nukleotydów oraz nukleozydów z przewodu pokarmowego, a także przedstawiono podstawowe etapy ich metabolizmu w komórkach organizmu. Produkty trawienia kwasów nukleinowych stanowią źródło ważnych cząsteczek sygnalizacyjnych i prekursorowych, mogą być również ponownie wykorzystane do budowy nowych cząsteczek kwasów nukleinowych w organizmie człowieka. W ostatnich latach największe zainteresowanie wzbudzają niskocząsteczkowe kwasy nukleinowe, takie jak niekodujące RNA (ncRNA), także obecne w żywności. Sugeruje się możliwość oddziaływania pokarmowego ncRNA na poziomie regulacji ekspresji genów w komórkach przewodu pokarmowego, a być może i innych tkankach konsumenta. Zarówno wartość odżywcza, jak i wpływ spożywanych kwasów nukleinowych na funkcjonowanie genomu i transkryptomu wskazują na konieczność rozpatrywania żywienia człowieka w kontekście nutrigenomiki.
\end{abstract}

Słowa kluczowe: kwasy nukleinowe, żywność, właściwości odżywcze, nutrigenomika

\section{Wprowadzenie}

Kwasy nukleinowe, tzn. DNA i różne klasy RNA, obecne są w każdej żywej komórce zwierzęcej i roślinnej jako podstawowy nośnik informacji genetycznej, powielanej i przekazywanej komórkom potomnym. Stanowią one również źródło informacji epigenetycznej regulującej funkcjonowanie genomu poprzez wpływ m.in. na strukturę chromatyny. Przede wszystkim jednak DNA jest podstawowym źródłem informacji

Mgr inż. J. Gtazowska, inż. U. Stankiewicz, dr hab. inż. A. Bartoszek, prof. nadzw., Katedra Chemii, Technologii i Biotechnologii Żywności, Wydz. Chemiczny, Politechnika Gdańska, ul. G. Narutowicza 11/12,80-233 Gdańsk. Kontakt: glazowska.joanna@gmail.com 
o budowie białek i niekodujących RNA (ncRNA), zapewniających prawidłowe funkcjonowanie komórek, a w konsekwencji całego organizmu.

W naukach o żywieniu kwasy nukleinowe uznawane były dotychczas za mało istotny składnik, a ich wartość odżywczą pomijano zapewne ze względu na szacunki sugerujące, że tylko ok. $5 \%$ spożywanych kwasów nukleinowych wykorzystywanych jest ponownie przez organizm do syntezy kwasów nukleinowych. DNA i RNA w większości trawione są w układzie pokarmowym i wchłaniane przede wszystkim w postaci nukleozydów. Nukleozydy purynowe przekształcane są do kwasu moczowego z wydzieleniem znaczącej ilości energii. W ostatnich latach dowiedziono jednak nie tylko budulcowych i energetycznych właściwości kwasów nukleinowych, ale także ich cech regulatorowych. Dotyczy to w szczególności niekodujących cząsteczek RNA, głównie tzw. microRNA (miRNA), które po spożyciu mogą mieć bezpośredni wpływ na ekspresję genów człowieka, a w konsekwencji na funkcjonowanie jego organizmu $[15,16,19]$. Kwasy nukleinowe stały się przedmiotem zainteresowania, a przemiany, jakim ulegają podczas przemysłowej produkcji żywności, obróbki kulinarnej oraz trawienia w przewodzie pokarmowym, są wskazywane jako istotne $\mathrm{w}$ technologii przetwarzania żywności, jak i na płaszczyźnie nutrigenomiki [6].

\section{Absorpcja i metabolizm kwasów nukleinowych}

Przewód pokarmowy jest główną drogą, którą „obce” dla organizmu substancje dostają się do jego wnętrza. Komórki nabłonka wyścielające wnętrze przewodu pokarmowego stanowią zatem potencjalne miejsce kontaktu z kwasami nukleinowymi obecnymi w żywności. Podczas trawienia większość obecnych w pokarmie łańcuchów kwasów nukleinowych ulega całkowitej degradacji do jednostek budulcowych. Kilka procent podlega jednak tylko fragmentacji na odcinki o długości od kilkuset do ok. 1700 par zasad. Wykazano, że nawet tak duże fragmenty mogą migrować do komórek nabłonka jelita, kępek Peyera, limfocytów, komórek wątroby oraz śledziony. Wykorzystanie techniki reakcji łańcuchowej polimerazy (PCR), Southern blottingu czy hybrydyzacji fluorescencyjnej in situ umożliwiło identyfikację tych fragmentów pokarmowego DNA we wspomnianych tkankach [12].

Do przewodu pokarmowego cząsteczki DNA i przynajmniej niektóre rodzaje RNA docierają $\mathrm{w}$ postaci nukleoprotein. Podczas trawienia kwasy nukleinowe uwalniane są z nich przez enzymy proteolityczne. Najnowsze badania wskazują także na możliwość wstępnego trawienia kwasów nukleinowych przez enzymy obecne w soku żołądkowym, m.in. przez pepsynę [10]. Reakcja ta jest dużo mniej specyficzna niż trawienie białek, może jednak zwiększać stopień trawienia kwasów nukleinowych $\mathrm{w}$ jelicie cienkim oraz stanowić pierwszą linię obrony przed inwazyjnym obcym DNA 


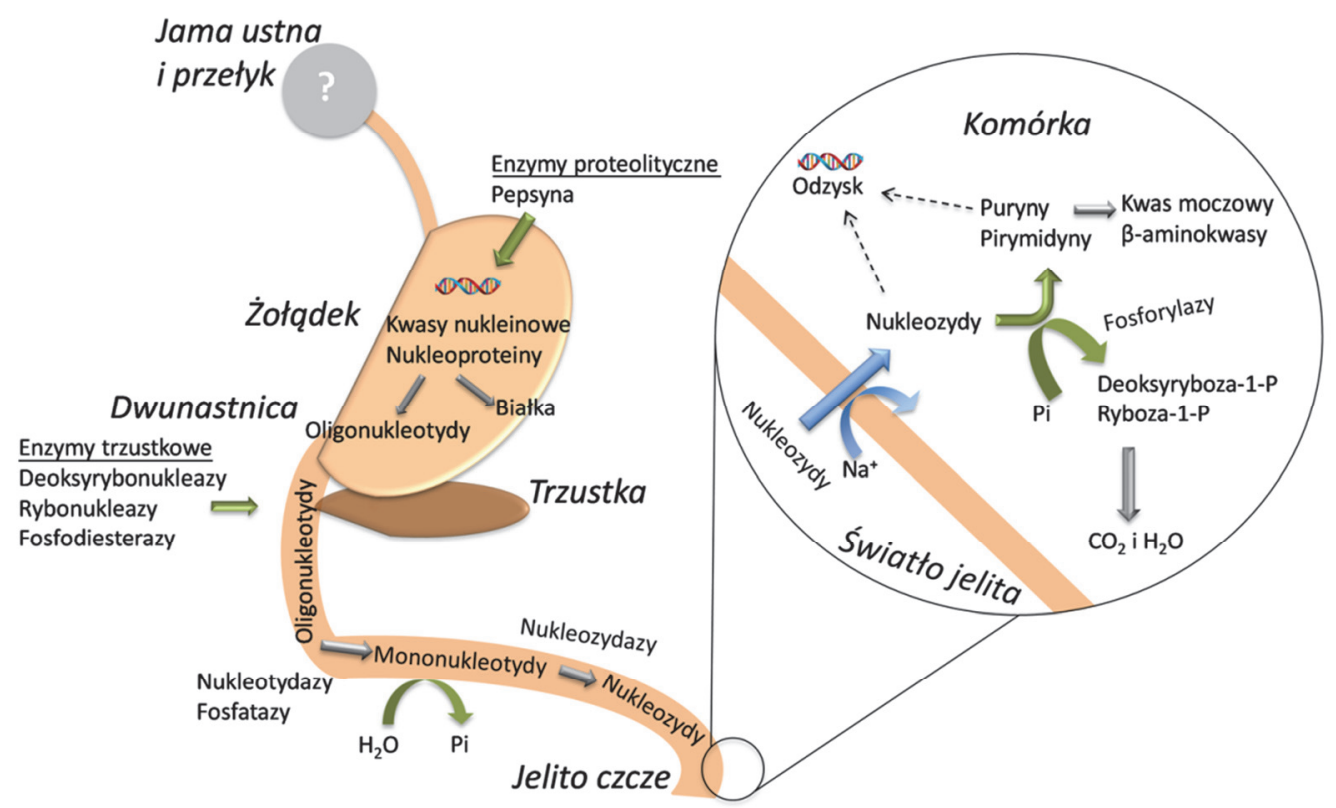

Objaśnienia / Explanatory notes:

$\beta$-aminokwasy / $\beta$-amino acids; białka / proteins; deoksyrybonukleazy / deoxyribonucleases; deoksyryboza-1-P / deoxyribose-1-P; dwunastnica / duodenum; enzymy proteolityczne / proteolytic enzymes; enzymy trzustkowe / pancreatic enzymes; fosfatazy / phosphatases; fosfodiesterazy / phosphodiesterases; fosforylazy / phosphorylases; jama ustna i przełyk / mounth and esophagus; jelito czcze / jejunum; komórka / cell; kwas moczowy / uric acid; kwasy nukleinowe / nucleic acids; mononukleotydy / mononucleotides; nukleoproteiny / nucleoproteins; nukleotydazy / nucleotidases; nukleozydazy / nucleosidases; nukleozydy / nucleosides; odzysk / salvage; oligonukleotydy / oligonucleotides; pepsyna / pepsine; pirymidyny / pyrimidines; puryny / purines; rybonukleazy / ribonucleases; ryboza-1-P / ribose-1-P; światło jelita / intestinal lumen; trzustka / pancreas; żołądek / stomach

Rys. 1. Proces trawienia oraz absorpcji kwasów nukleinowych w układzie pokarmowym

Fig. 1. Digestion process and absorption of nucleic acids in digestive tract

Źródło: Opracowanie własne / Source: the authors' own study

lub RNA. W dwunastnicy kwasy nukleinowe degradowane są przez nukleazy trzustkowe do mono-, di-, tri- i oligonukleotydów. W jelicie cienkim, w obecności oligonukleozydaz, kwasy nukleinowe trawione są do pojedynczych nukleotydów. Fosfoesterazy hydrolizują następnie wiązania fosfodiestrowe, odłączając grupę ortofosforanową i uwalniając poszczególne nukleozydy. Dalszy ich rozpad prowadzi do otrzymania zasad purynowych lub pirymidynowych. Uproszczony schemat trawienia kwasów nukleinowych w przewodzie pokarmowym przedstawiono na rys. 1 .

Głównym produktem trawienia kwasów nukleinowych są nukleozydy wchłaniane z przewodu pokarmowego przez enterocyty, zarówno na drodze dyfuzji wspomaganej, jak i poprzez transport aktywny. Największe wchłanianie zachodzi w jelicie czczym. 
Zaabsorbowane nukleozydy purynowe są szybko metabolizowane i przekształcane do kwasu moczowego, natomiast nukleotydy pirymidynowe - do $\beta$-aminokwasów.

Na rys. 2. przedstawiono schemat degradacji nukleotydów purynowych do kwasu moczowego wraz z wartościami energii swobodnej Gibbsa poszczególnych reakcji. Szacuje się, że w przypadku puryn końcowe etapy katabolizmu obejmujące przejścia od adenozyny do kwasu moczowego pozwalają uzyskać $71,9 \mathrm{kcal} / \mathrm{mol}$ energii. Dla porównania szlak glikolityczny od glukozy do kwasu pirogronowego dostarcza $27,8 \mathrm{kcal} / \mathrm{mol}$, a szlak $\beta$-oksydacji kwasów tłuszczowych do acetylo-CoA, np. dla kwasu palmitynowego dostarcza $184,6 \mathrm{kcal} / \mathrm{mol}$.

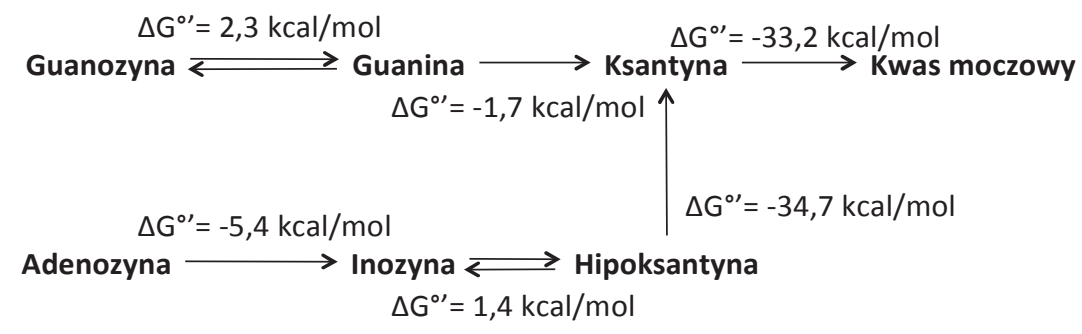

Szlak glikolizy:

$\Delta \mathrm{G}^{\circ \prime}=-27,8 \mathrm{kcal} / \mathrm{mol}$

$\mathrm{C}_{6} \mathrm{H}_{12} \mathrm{O}_{6}+2 \mathrm{NAD}^{+}+2 \mathrm{ADP}+2 \mathrm{Pi} \longrightarrow 2 \mathrm{C}_{3} \mathrm{H}_{4} \mathrm{O}_{3}+2 \mathrm{NADH}+2 \mathrm{H}^{+}+2 \mathrm{ATP}+2 \mathrm{H}_{2} \mathrm{O}$

Szlak degradacji kwasów tłuszczowych:

$\Delta \mathrm{G}^{\circ \prime}=-184,6 \mathrm{kcal} / \mathrm{mol}$
$\mathrm{CH}_{3}\left(\mathrm{CH}_{2}\right)_{14} \mathrm{CO}-\mathrm{COA}+7 \mathrm{FAD}+7 \mathrm{H}_{2} \mathrm{O}+7 \mathrm{CoA}+7 \mathrm{NAD}^{+} \longrightarrow 8 \mathrm{CH}_{3} \mathrm{CO}-\mathrm{CoA}+7 \mathrm{FADH}_{2}+7 \mathrm{NADH}+7 \mathrm{H}^{+}$

Objaśnienia / Explanatory notes:

adenozyna / adenosine; guanina / guanine; guanozyna / guanisine; hipoksantyna / hypoxantine; inozyna / inosine; ksantyna / xanthine; kwas moczowy / uric acid; szlak degradacji kwasów tłuszczowych / fatty acid degradation pathway; szlak glikolizy / glycolytic pathway

Rys. 2. Schemat przemian nukleozydów purynowych do kwasu moczowego wraz z energią swobodną Gibbsa dla poszczególnej reakcji oraz wartości $\Delta \mathrm{G}^{\circ}$ dla szlaku glikolitycznego oraz szlaku $\beta$-oksydacji kwasów tłuszczowych na przykładzie kwasu palmitynowego

Fig. 2. Conversion scheme of purine nucleosides into uric acid with Gibbs free energy for individual reactions and $\Delta \mathrm{G}^{\circ}$, values for glycolytic pathway and fatty acid $\beta$-oxidation pathway exemplified by palmitic acid

Opracowano na podstawie [14, 20] / Developed based on [14, 20]

W badaniach na zwierzętach wykazano, że tylko $2 \div 5 \%$ spożywanych nukleotydów wchłanianych jest z przewodu pokarmowego i wbudowywanych w struktury komórkowe. Ma to miejsce szczególnie w młodym wieku osobniczym podczas intensyw- 
nego wzrostu organizmu, a także w okresach ograniczonej dostępności pożywienia lub pokarmu ubogiego w składniki odżywcze [2, 3]. Pod tym względem nie bez znaczenia są również kwasy nukleinowe i ich pochodne uwalniane ze złuszczającego się nabłonka wyścielającego wnętrze jelita. Stanowią one część nukleotydów wchłanianych i wykorzystywanych ponownie przez organizm w procesie odzysku oraz tworzenia nowych kwasów nukleinowych. W przypadku szczurów może to być nawet do $30 \mathrm{mg}$ kwasów nukleinowych na dobę [3].

\section{Metabolizm puryn}

Pierścień purynowy syntezowany jest w komórkach ssaków z glicyny, asparaginianu, glutaminy, pochodnych tetrahydrofolianu i $\mathrm{CO}_{2}$. Do biosyntezy inozynomonofosforanu (IMP), produktu wyjściowego do syntezy adeniny i guaniny, konieczne jest zużycie 6 cząsteczek ATP. Szlak metaboliczny puryn przedstawiono schematycznie na rys. 3 .

Odzysk nukleotydów możliwy jest dzięki obecności enzymów: fosforybozylotransferazy guaniny-hipoksantyny, która katalizuje reakcję konwersji guaniny w obecności 5-fosforybozylo-1-pirofosforanu do guanozyno-5'-monofosforanu (GMP) oraz hipoksantyny w obecności 5-fosforybozylo-1-pirofosforanu do IMP, a także adenino fosforybozylotransferazy katalizującej konwersję adeniny w obecności 5-fosforybozylo-1-pirofosforanu do adenozyno-5'-monofosforanu (AMP). Uruchomienie szlaku odzysku nukleotydów (powstawanie GMP i AMP) blokuje syntezę nukleotydów de novo. Ze względu na to, że synteza nukleotydów jest procesem kosztownym energetycznie, w komórce regulowana jest na bardzo wielu poziomach [3].

Puryny i ich pochodne przekształcane są do kwasu moczowego i w tej postaci usuwane $\mathrm{z}$ moczem $\mathrm{z}$ organizmu. W procesie tym udział biorą m.in. nukleazy specyficzne dla RNA i DNA, nukleotydazy i alkaliczne oraz kwasowe fosfatazy hydrolizujące wiązania 3'- i 5'-NT, deaminazy AMP i deaminazy adenozyny, a także fosforylaza purynowych nukleozydów hydrolizująca nukleozydy do zasad. Końcowym etapem przemian nukleotydów purynowych jest tworzenie kwasu moczowego przez oksydazę ksantynową. 


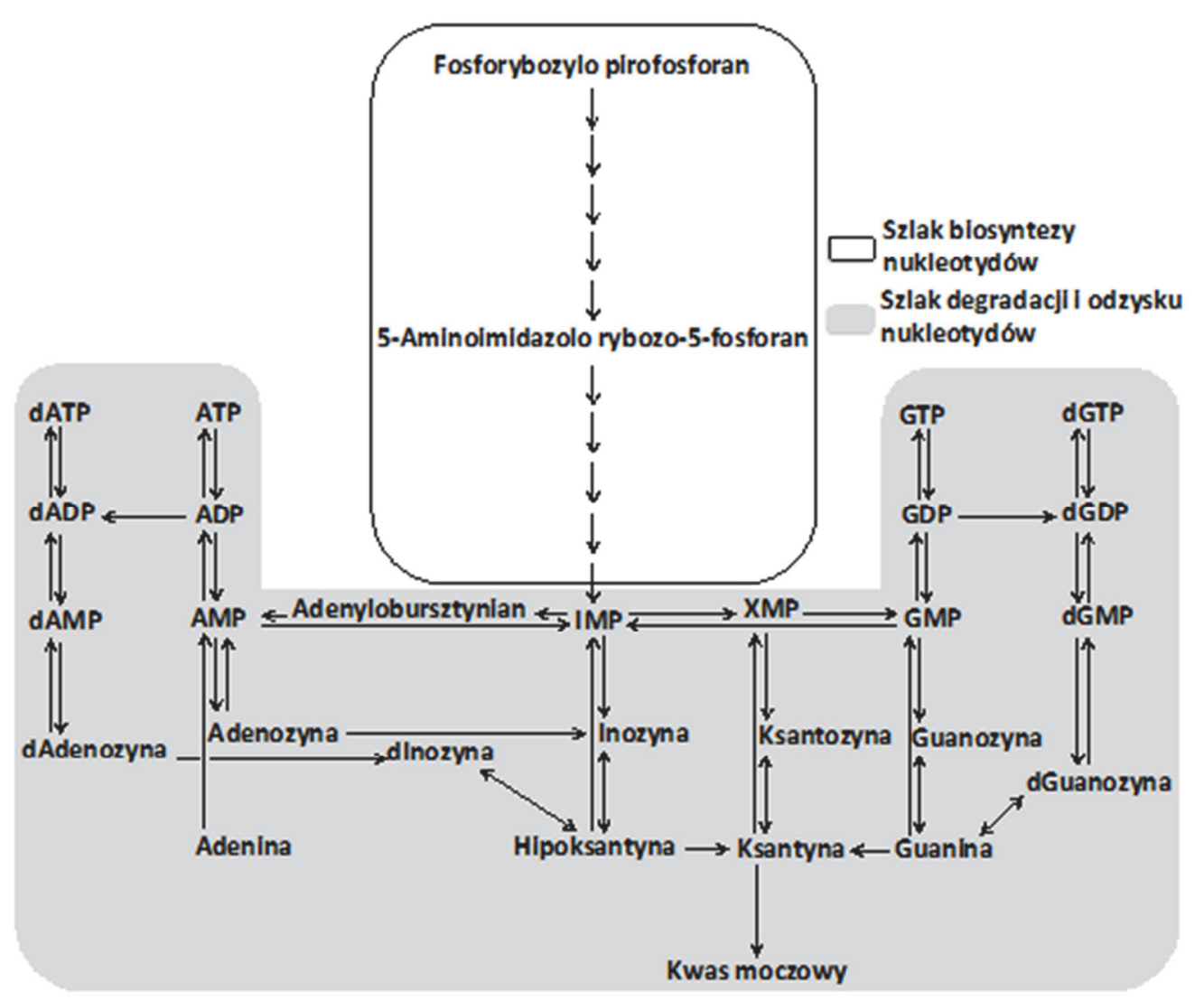

Objaśnienia / Explanatory notes:

ATP - adenozyno-5'-trifosforan / adenosine 5'-triphosphate; dATP - deoksyadenozyno-5'-trifosforan / deoxyadenosine 5'-triphosphate; ADP - adenozyno-5'-difosforan / adenosine-5'-diphosphate; dADP deoksyadenozyno-5'-difosforan / deoxyadenosine-5'-diphosphate; AMP - adenozyno-5'-monofosforan / adenosine-5'-monophosphate; dAMP - deoksyadenozyno-5'-monofosforan / deoxyadenosine-5'monophosphate; IMP - inozyno-5'-monofosforan / inosine-5'-monophosphate; XMP - ksantozyno-5'monofosforan / xanthosine-5'-monophosphate; GTP - guanozyno-5'-trifosforan / guanosine-5'triphosphate; dGTP - deoksyguanozyno-5'-trifosforan / deoxyguanosine-5'-triphosphate; GDP guanozyno-5'-difosforan / guanosine-5'-diphosphate; dGDP - deoksyguanozyno-5'-difosforan / deoxyguanosine 5'-diphosphate; GMP - guanozyno-5'-monofosforan / guanosine-5'-monophosphate; dGMP - deoksyguanozyno-5'-monofosforan / deoxyguanosine-5'-monophosphate.

Rys. 3. Schemat przedstawiający szlak metaboliczny puryn

Fig. 3. Scheme of purine metabolic pathway

Opracowano na podstawie $[3,20] /$ Developed based on $[3,20]$ 
Metabolizm pirymidyn

Cząsteczka pirymidyny syntezowana jest w komórkach $\mathrm{z}$ jednej cząsteczki asparaginianu, glutaminy i cząsteczki $\mathrm{CO}_{2}$. Oprócz tego do zsyntezowania cząsteczki monofosforanu urydyny (UMP) potrzebne są 4 wysokoenergetyczne reszty fosforanowe. Szlak biosyntezy pirymidyn przedstawiono na rys. 4. Odzysk pirymidyn zachodzi w komórce na drodze konwersji pirymidyny w obecności 5-fosforybozylo-1pirofosforanu do monofosforanu pirymidyny katalizowanej przez fosforybozylotransferazę pirymidyny [3].

$\mathrm{W}$ procesie degradacji pierwszym etapem jest konwersja nukleotydów pirymidynowych do nukleozydów, a następnie do uracylu lub tyminy. Cytydyna ulega deaminacji do urydyny, która z kolei ulega deglikozylacji do uracylu. Uracyl i tymina ulegają dalszym rozkładom odpowiednio do $\beta$-alaniny i kwasu $\beta$-aminoizomasłowego.

\section{Kwasy nukleinowe jako składniki odżywcze w żywności}

Kwasy nukleinowe obok białek, tłuszczów, witamin i węglowodanów stanowią naturalny składnik produktów żywnościowych. Produkty ich trawienia w układzie pokarmowym są wchłaniane i przynajmniej częściowo wykorzystywane do syntezy kwasów nukleinowych $\mathrm{w}$ organizmie człowieka. Jest to ważna oszczędność energetyczna, bowiem biosynteza 1 cząsteczki zasady azotowej np. guanozyno-5'monofosforanu wymaga nakładu 7 cząsteczek ATP czyli ok. $49 \mathrm{kcal} / \mathrm{mol}$. Nie ma danych w przypadku organizmu ludzkiego by degradacja kwasów nukleinowych służyła pozyskiwaniu energii, choć taką możliwość wykazano przynajmniej dla niektórych mikroorganizmów [5]. Wiadomo jednak, że ograniczona ilość lub całkowity brak tych składników w codziennej diecie może prowadzić do zaburzeń i nieprawidłowości w normalnym wzroście i rozwoju organizmu. Wykazano, że brak RNA w spożywanych produktach może powodować znaczące zmniejszenie zawartości RNA w komórkach jelita cienkiego [1]. Dieta uboga w kwasy nukleinowe lub ich pozbawiona powoduje nie tylko znaczne zmniejszenie zawartości całkowitego RNA, ale także białek w komórkach jelita cienkiego oraz grubego. Wskazuje to na występowanie mechanizmów kontrolujących syntezę specyficznych białek w zależności od ilości spożywanych kwasów nukleinowych [3].

Nukleotydy obecne w żywności działają stymulująco na wzrost i dojrzewanie komórek jelita. W warunkach in vitro wykazano też, że deficyt nukleotydów w diecie obniża zdolność organizmu do reakcji immunologicznej przeciwko patogenom grzybiczym oraz bakteryjnym. Główne zdrowotne efekty spożywania diety bogatej w kwasy nukleinowe przedstawiono w tab. 1. 


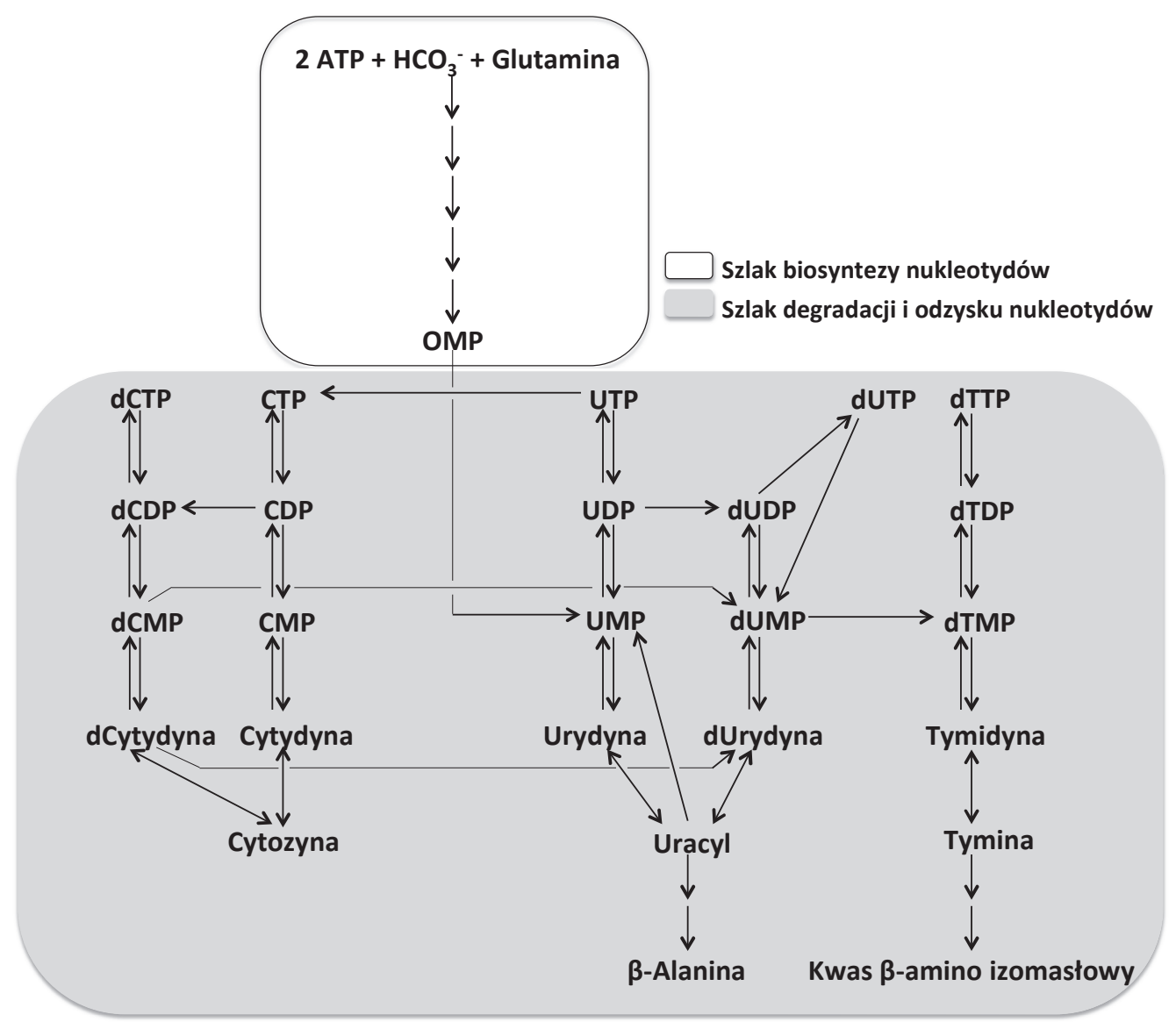

Objaśnienia / Explanatory notes:

OMP - orotydyno-5'-monofosforan / orotidine-5'-monophosphate; CTP - cytydyno-5'-trifosforan / cytidine 5'-triphosphate; dCTP - deoksycytydyno-5'-trifosforan / deoxycytidine 5'-triphosphate; CDP cytydyno-5'-difosforan / cytidine 5'-diphosphate; dCDP - deoksycytydyno-5'-difosforan / deoxycytidine 5'-diphosphate; CMP - cytydyno-5'-monofosforan / cytidine 5'-monophosphate; dCMP deoksycytydyno-5'-monofosforan / deoxycytidine 5'-monophosphate; UTP - urydyno-5'-trifosforan / uridine-5'-triphosphate; dUTP - deoksyuryduno-5'-trifosforan / deoxyuridine-5'-triphosphate; UDP urydyno-5'-difosforan / uridine-5'-diphosphate; dUDP - deoskyurydyno-5' -difosforan / deoxyuridine-5'diphosphate; UMP - urydyno-5' -monofosforan / uridine-5'-monophosphate; dUMP - deoksyurydyno-5'monofosforan / deoxyuridine-5'-monophosphate; dTTP - deoksytymidyno-5'-trifosforan / deoxythymidin5'-triphosphate; dTDP - deoksytymidyno-5'-difosforan / deoxythymidin-5'-diphosphate; dTMP deoksytymidyno-5' -monofosforan / deoxythymidin-5'-monophosphate.

Rys. 4. Schemat przedstawiający szlak metaboliczny pirymidyn

Fig. 4. Scheme of pyrimidine metabolic pathway

Opracowano na podstawie [3, 20] / Developed based on [3, 20] 
Spożywanie kwasów nukleinowych, nukleotydów oraz nukleozydów powoduje $\mathrm{w}$ organizmie zwiększenie produkcji kwasu moczowego oraz jego pochodnych $\mathrm{w}$ surowicy. Zbyt wysoki poziom tych metabolitów, szczególnie w przypadku nieprawidłowego odczynu krwi, może prowadzić do powstawania kryształów kwasu moczowego, a w konsekwencji do rozwoju tzw. dny [7].

Tabela 1. Zdrowotne efekty spożywania żywności wzbogaconej nukleotydami w organizmach ludzi i zwierząt

Table 1. Health effects of consuming food enriched with nucleotides in human and animal bodies

\begin{tabular}{||l|c|c||}
\hline \multicolumn{1}{|c|}{$\begin{array}{c}\text { Efekt zdrowotny } \\
\text { Health effect }\end{array}$} & $\begin{array}{c}\text { Ludzie } \\
\text { Humans }\end{array}$ & $\begin{array}{c}\text { Zwierzęta } \\
\text { Animals }\end{array}$ \\
\hline $\begin{array}{l}\text { Stymulacja wzrostu komórek jelita cienkiego } \\
\text { Stimulation of small intestinal cells growth }\end{array}$ & $\begin{array}{c}\text { b.d. } \\
\text { n.d. }\end{array}$ & + \\
\hline $\begin{array}{l}\text { Zwiększenie aktywności disacharydaz jelita cienkiego } \\
\text { Increased activity of disaccharidases in small intestine }\end{array}$ & $\begin{array}{c}\text { b.d. } \\
\text { n.d. }\end{array}$ & $+/-$ \\
\hline $\begin{array}{l}\text { Przekrwienie jelit } \\
\text { Intestinal hyperaemia }\end{array}$ & $\begin{array}{l}\text { b.d. } \\
\text { n.d. }\end{array}$ & + \\
\hline $\begin{array}{l}\text { Ochrona przeciwko biegunce } \\
\text { Protection against diarrhea }\end{array}$ & + & + \\
\hline $\begin{array}{l}\text { Wpływ na florę kałową } \\
\text { Effect on fecal flora }\end{array}$ & + & $\begin{array}{l}\text { b.d. } \\
\text { n.d. }\end{array}$ \\
\hline $\begin{array}{l}\text { Wzmocniona odporność komórkowa } \\
\text { Enhanced cellular immunity }\end{array}$ & + & $+/-$ \\
\hline $\begin{array}{l}\text { Wzmocniona odporność humoralna } \\
\text { Enhanced humoral immunity }\end{array}$ & $\begin{array}{l}\text { b.d. } \\
\text { n.d. }\end{array}$ & + \\
\hline $\begin{array}{l}\text { Wpływ na strukturę wątroby } \\
\text { Effect on liver structure }\end{array}$ & $\begin{array}{l}\text { b.d. } \\
\text { n.d. }\end{array}$ & + \\
\hline $\begin{array}{l}\text { Wzrost zawartości długołańcuchowych nienasyconych kwasów } \\
\text { tłuszczowych we krwi } \\
\text { Increased content of long chain unsaturated fatty acids in blood }\end{array}$ & $+/-$ & $+/-$ \\
\hline $\begin{array}{l}\text { Wpływ na lipoproteiny w surowicy krwi } \\
\text { Effect on serum lipoproteins }\end{array}$ & $\begin{array}{l}\text { b.d. } \\
\text { n.d. }\end{array}$ \\
\hline
\end{tabular}

Objaśnienia / Explanatory notes:

b.d. - brak danych / n.d. - no data; + - potwierdzone działanie prozdrowotne / confirmed healthpromoting effect; +/- - możliwe działanie prozdrowotne / possible health-promoting effect

Żródło: [3] / Source: [3]

Szacuje się, że w zależności od stosowanej diety dzienna dawka spożywanych kwasów nukleinowych waha się $\mathrm{w}$ granicach $0,1 \div 1$ g/osobę [7]. Jednocześnie sugeruje się, że bezpieczna ilość kwasów nukleinowych spożywanych przez dorosłego człowieka to $2 \mathrm{~g}$ /dzień [3], przy czym zaleca się spożycie maksymalnie do $4 \mathrm{~g} /$ dzień DNA oraz RNA [1]. Ze względu na różnorodność produktów oraz stopień ich przetwo- 
rzenia, a przede wszystkim brak wiarygodnych danych, trudno jest jednoznacznie określić ilość kwasów nukleinowych obecnych w żywności oraz tych spożywanych.

\section{Potencjalna żywieniowa rola niekodujących cząsteczek RNA}

Obecnie uwaga badaczy skierowana jest na rolę, jaką mogą odgrywać różnego rodzaju cząsteczki RNA, a w szczególności miRNA, w funkcjonowaniu organizmów żywych, przede wszystkim człowieka. Większość prowadzonych badań dotyczy powiązania między ekspresją pewnych ncRNA a zagrożeniem zdrowotnym. Potwierdzenie takiej zależności zwróciło jednak uwagę także na obecność tych cząsteczek w żywności. Wstępne dane uzyskane $\mathrm{w}$ badaniach in vitro i in vivo wskazują, że miRNA mogą wnikać z pokarmu do organizmu człowieka i pełnić w nim funkcje regulatorowe [19]. Wyniki te, obok entuzjazmu związanego z nowymi możliwościami terapii typu „leczenie poprzez jedzenie”, wzbudzają również wiele kontrowersji i sceptycyzmu [15, 17], a formułowane hipotezy wymagają jeszcze wielu badań i weryfikacji.

Obok mRNA kodujących białka występuje wiele form ncRNA pełniących przede wszystkim funkcje regulatorowe. Na podstawie badań nad właściwościami fizykochemicznymi tych kwasów nukleinowych stwierdzono, że w porównaniu z większymi cząsteczkami RNA, niskocząsteczkowe RNA są odporne na ogrzewanie, na niskie/wysokie $\mathrm{pH}$ (stabilność podczas traktowania przez $3 \mathrm{~h}$ przez środowisko o $\mathrm{pH}=1$ i $\mathrm{pH}=13$ ), długi okres przechowywania, cykliczne rozmrażanie i zamrażanie (10 cykli) [4]. A zatem potencjalnie miRNA mogłyby przetrwać zarówno przetwarzanie żywności, jak i warunki w układzie pokarmowym.

Pod względem żywieniowym najbardziej interesujące mogą być właśnie miRNA. Są to jednoniciowe biomolekuły kodowane w genomach większości organizmów, regulujące ekspresję genów na poziomie potranskrypcyjnym. Produkt powstały na skutek transkrypcji (pri-miRNA) jest długą (kilkaset nukleotydów), jednoniciową cząsteczką RNA, przyjmującą strukturę tzw. spinki do włosów. Dojrzewanie miRNA przebiega dwuetapowo. W pierwszym etapie uczestniczy enzym o aktywności rybonukleazy III Drosha, który katalizuje wycięcie fragmentu o długości 70 nukleotydów, odpowiadającego za pofałdowanie struktury. Następnie pri-miRNA transportowany jest przez białko Exportin $5 \mathrm{z}$ jądra do cytoplazmy, gdzie dochodzi do drugiego etapu dojrzewania. Bierze w nim udział rybonukleaza Dicer, która przecina obie nici w odległości 21 nukleotydów od miejsca jej związania z pri-miRNA. Dupleksy są szybko rozdzielane na dwie niezależne nici, z których jedna jest degradowana, natomiast druga - włączana w kompleks RISC (RNA - induced silencing complex; pol. - kompleks wyciszający indukowany RNA), na który składają się m.in. białka Argonaut. Uważa się, że kompleks ten może regulować ekspresję genów u większości organizmów eukariotycznych, w tym ssaków i ludzi. Nić miRNA obecna w kompleksie RISC łączy się na zasadzie komplementarności z mRNA w jego części określonej jako UTR (untranslated region; 
pol. - region niepodlegający translacji). W zależności od stopnia komplementarności z obszarem 3'-UTR mRNA dochodzi do inhibicji translacji bez zniszczenia transkryptu (częściowa komplementarność) lub degradacji mRNA (komplementarność całkowita). Zgodnie z obecnym stanem wiedzy w ludzkim organizmie cząsteczki miRNA (szacuje się, że jest ich ok. 1000) regulują ekspresję 30 \% genów. Odgrywają one przez to dużą rolę w procesach fizjologicznych i patologicznych, mają też znaczenie dla procesu embriogenezy. Zaburzenia w ekspresji miRNA są wiązane także z powstawaniem nowotworów i rozwojem innych chorób. Zatem obecność tych cząsteczek w żywności wzbudza zrozumiałe zainteresowanie, które wzrośnie, o ile potwierdzona zostanie ich zdolność do wnikania z pokarmu do organizmu człowieka.

Jednym z najlepiej przebadanych pokarmowych źródeł kwasów nukleinowych jest mleko kobiece, które stanowi jedyny i do tej pory niezastąpiony w pełni pokarm dla nowonarodzonych niemowląt. Wiadomo, że obok dostarczania substancji odżywczych dla młodego organizmu, pełni ono ważną rolę regulatorową, dostarczając czynników kształtujących metabolizm, układ odpornościowy i inne funkcje w organizmie noworodka. Ważnymi składnikami mleka kobiecego są nukleozydy, nukleotydy oraz kwasy nukleinowe. We wczesnych etapach laktacji zawartość kwasów nukleinowych w mleku kobiecym waha się od 20 do $70 \mu \mathrm{g} / \mathrm{ml}$ i wraz z postępem laktacji zmniejsza się do poziomu $27 \div 30 \mu \mathrm{g} / \mathrm{ml}$ mleka. Przeważającą formą są niskocząsteczkowe kwasy nukleinowe o średniej długości do 100 par zasad, o charakterze RNA, wykazujące obecność II- i III-rzędowych form przestrzennych przypominających kształt spinki do włosów oraz inne formy dwuniciowe. Sekwencje wyizolowanych z mleka oligonukleotydów odpowiadają fragmentom rRNA oraz tRNA występujących w komórkach organizmu ludzkiego $[9,13]$.

W przeciwieństwie do badań opisanych wyżej, Kosaka i wsp. [8] stwierdzili w mleku kobiecym bardzo małą zawartość rRNA, a wyizolowane polinukleotydy charakteryzowały się długością ok. 300 par zasad. Wykazali oni także obecność miRNA o zawartości $0,0097 \div 0,2282 \mu \mathrm{g} / \mathrm{ml}$. Analiza jakościowa potwierdziła obecność 281 spośród 723 znanych wówczas cząsteczek miRNA, głównie takich, których funkcje związane są z układem immunologicznym (tab. 2). Wykazano trwałość miRNA w obecności rybonukleaz. Cząsteczki te nie są też degradowane do nukleotydów, a ich stabilność w pH równym 1 przez ok. $1 \mathrm{~h}$ wskazuje na możliwość przetrwania w warunkach panujących w żołądku noworodka. Oznacza to, że dzięki tej odporności cząsteczki miRNA mogą dotrzeć do jelita i tam, po ewentualnym wchłonięciu, modulować ekspresję genów [8]. 
Tabela 2. Przykładowe miRNA występujące w mleku kobiecym i ich funkcja

Table 2. Examples of miRNAs present in human milk and their function

\begin{tabular}{|c|c|}
\hline $\begin{array}{l}\text { Skrócona nazwa cząsteczki } \\
\text { Abbreviated name of } \\
\text { molecule }\end{array}$ & Funkcja / Function \\
\hline miR-155 & $\begin{array}{l}\text { Reguluje dojrzewanie limfocytów B i T oraz stymuluje wrodzoną odpo- } \\
\text { wiedź immunologiczną. } \\
\text { Regulates maturation of B and T lymphocytes and stimulates innate } \\
\text { immune response. }\end{array}$ \\
\hline miR-181a i miR-181b & $\begin{array}{l}\text { Regulują różnicowanie limfocytów B oraz selekcję limfocytów typu Th. } \\
\text { Regulate differentiation of B cells and selection of Th lymphocytes. }\end{array}$ \\
\hline miR-17 i miR-92 & $\begin{array}{l}\text { Regulują w szerokim zakresie rozwój limfocytów typu B, T oraz mono- } \\
\text { cytów. } \\
\text { Broadly regulate development of B, T lymphocytes, and monocytes. }\end{array}$ \\
\hline $\operatorname{miR}-125 b$ & $\begin{array}{l}\text { Negatywny regulator produkcji, aktywacji oraz czułości czynnika } \alpha \\
\text { związanego z nekrozą nowotworów. } \\
\text { Negative regulator of production, activation, and sensitivity of } \alpha \text { factor } \\
\text { related to tumour necrosis. }\end{array}$ \\
\hline $\operatorname{miR}-146 b$ & $\begin{array}{l}\text { Negatywny regulator wrodzonej odpowiedzi immunologicznej. } \\
\text { Negative regulator of innate immune response. }\end{array}$ \\
\hline $\operatorname{miR}-223$ & $\begin{array}{l}\text { Regulator proliferacji oraz aktywacji neutrofilów. } \\
\text { Regulator of neutrophils proliferation and activation. }\end{array}$ \\
\hline let-7i & $\begin{array}{l}\text { Regulator receptora TLR4 w ludzkich cholangiocytach. } \\
\text { TLR4 receptor regulator in human cholangiocytes. }\end{array}$ \\
\hline
\end{tabular}

Opracowano na podstawie [8] / Developed based on [8]

Począwszy od roku 2013 ukazują się publikacje z wynikami badań dotyczących wchłaniania przez organizmy kręgowców miRNA pochodzącego z pokarmu, a także wynikających $\mathrm{z}$ tego konsekwencji. Wskazują one, że miRNA mogą być wchłaniane przez osoby dorosłe z przewodu pokarmowego do komórek nabłonka jelita cienkiego, tam umieszczane $\mathrm{w}$ micelach chroniących je przed degradacją, a następnie transportowane naczyniami krwionośnymi po całym organizmie. Uważa się także, że mikroflora układu pokarmowego może w znaczący sposób ułatwiać wchłanianie cząsteczek RNA. Wprawdzie poznanie tych mechanizmów ma na celu znalezienie w przyszłości sposobów wykorzystania miRNA, np. w terapii przeciwnowotworowej poprzez doustne podanie pacjentowi odpowiednio dobranego zestawu supresorowych miRNA, jednak ich poznanie będzie miało ogromne znaczenie także dla nauk o żywieniu [11, 15, 19].

Z kolei sceptycy nie są przekonani, że miRNA wchłaniają się z przewodu pokarmowego ludzi niecierpiących na choroby układu pokarmowego i stosujących odpowiednio zbilansowaną dietę. Uważają, że możliwość wchłaniania dostarczanego z pożywieniem RNA występuje wyłącznie u osób z zaburzeniami funkcjonowania oraz organizacji komórek nabłonka wyścielającego jelito cienkie, co generalnie wiąże się ze 
zwiększoną przenikalnością substancji chemicznych z przewodu pokarmowego do komórek nabłonka oraz układu krwionośnego [17, 18]. Niewątpliwie badania najbliższych lat rozstrzygną kwestię udziału regulatorowych cząsteczek ncRNA z pokarmu w regulacji genów człowieka, co być może otworzy nowy rozdział badań nad żywnością i żywieniem.

\section{Podsumowanie}

Kwasy nukleinowe są obecne w spożywanej przez ludzi surowej i nisko przetworzonej żywności, szczególnie w warzywach, rybach, owocach morza oraz mięsie. Zawartość kwasów nukleinowych w żywności może wynosić nawet do $10 \%$ s.m. Ich obecność ma wpływ na sensoryczne właściwości spożywanej żywności, głównie poprzez obecność nukleotydu guanozyno-5'-monofosforanu (GMP), który uznawany jest za wzmacniacz smaku umami. Kwasy nukleinowe stanowią również ważne składniki żywności, istotne do poprawnego funkcjonowania organizmu ludzkiego. Mają wpływ na poprawne funkcjonowanie układu pokarmowego oraz odpornościowego człowieka, a także są źródłem energii oraz wielu cząsteczek sygnalizacyjnych w organizmie. W ostatnich latach odkryto, że krótkie fragmenty kwasów nukleinowych (miRNA) wchłanianych z żywności mogą mieć wpływ na regulację ekspresji genów, m.in. komórek układu pokarmowego. Ma to szczególne znaczenie dla prawidłowego rozwoju układu pokarmowego noworodków, u których kwasy nukleinowe obecne w mleku matki stymulują m.in. prawidłowe dojrzewanie funkcji trawiennych. Dodatkowo, ze względu na dużą różnorodność biochemiczną oraz metaboliczną ludzi, ważnym aspektem w tworzeniu nowoczesnych zaleceń żywieniowych staje się dążenie do personalizacji diety, co pozwoli w szerszym aspekcie wykorzystać prozdrowotnie obecne w niej składniki, w tym kwasy nukleinowe. $Z$ tego powodu tak ważne staje się poznanie dokładnych mechanizmów oraz roli, jaką odgrywają kwasy nukleinowe w żywności i żywieniu człowieka. Obecny stan wiedzy na temat roli i zawartości tych makromolekuł jest niewystarczający, co przedstawiono w przytoczonych danych literaturowych. Istotne staje się poznanie szczegółowych zawartości kwasów nukleinowych obecnych w spożywanych surowcach i produktach żywnościowych w celu zaktualizowania obecnie obowiązujących dla nich norm żywieniowych, a także mechanizmu ich wchłaniania z przewodu pokarmowego do komórek nabłonka oraz przenikania do krwiobiegu.

\section{Podziękowania}

Autorki sktadaja podziękowania Panu prof. dr hab. inż. Zdzisławowi E. Sikorskiemu (Katedra Chemii, Technologii i Biotechnologii Żywności, Wydziat Chemiczny, Politechnika Gdańska) za cenne uwagi edytorskie. Publikacja przygotowana została w ramach projektu: VEGFRUT nr 605/L-4/2012 pt. ,, Wykorzystanie technologii mikro- 
falowych $w$ przetwórstwie warzyw i owoców w celu uzyskania produktów żywnościowych o wysokiej jakości zdrowotnej" finansowanego przez Narodowe Centrum Badań i Rozwoju, program LIDER.

\section{Literatura}

[1] Adjei A.A., Shigeru Y., Kulkarni A.: Nucleic acids and/or their components: A possible role in immune function. J. Nutr. Sci. Vitaminol, 1995, 1 (41), 1-16.

[2] Carver J.D.: Dietary nucleotides: Effects on the immune and gastrointestinal systems. Acta Paediatr. Suppl., 1999, 88 (430), 83-88.

[3] Carver J.D., Walker A.W.: The role of nucleotides in human nutrition. J. Nutr. Biochem, 1995, 2 (6), 58-72.

[4] Chen X., Ba Y., Ma L., Cai X., Yin Y., Wang K., Guo J., Zhang Y., Chen J., Guo X., Li Q., Li X., Wang W., Zhang Y., Wang J., Jiang X., Xiang Y., Xu C., Zheng P., Zhang J., Li R., Zhang H., Shang X., Gong T., Ning G., Wang J., Zen K., Zhang J., Zhang C.-Y.: Characterization of micro RNAs in serum: A novel class of biomarkers for diagnosis of cancer and other diseases. Cell Res., 2008, 18, 997-1006.

[5] Finkel S.E., Kolter R.: DNA as a nutrient: Novel role for bacterial competence gene homologs. J. Bacteriol., 2001, 21 (183), 6288-6293.

[6] Gętek M., Czech M., Fizia K., Białek-Dratwa A., Muc-Wierzgoń M., Kokot T., Nowakowska-Zajdel E.: Nutrigenomika - bioaktywne składniki żywności. Postępy Hig. Med. Dośw., 2013, 67, 255-260.

[7] Jonas D.A., Elmadfa I., Engel K.H., Heller K.J., Kozianowski G., König A., Müller D., Narbonne J.F., Wackernagel W., Kleiner J.: Safety considerations of DNA in food. Ann. Nutr. Metab., 2001, 6 (45), 235-254

[8] Kosaka N., Izumi H., Sekine K., Ochiya T.: MicroRNA as a new immune-regulatory agent in breast milk. Silence, 2010, 1 (7), 1-8.

[9] Kuligina E.V., Semenov D.V., Shevyrina O.N., Richter V.A.: Ribonucleic acids of human milk. Nucleos. Nucleot. Nucl., 2004, 6-7 (23), 837-842.

[10] Liu Y., Zhang Y., Dong P., An R., Xue C., Ge Y., Wei L., Liang X.: Digestion of nucleic acids starts in the stomach. Scientific Reports, 2015, 5, \# 11936, 1-11.

[11] Mlotshwa S., Pruss G.J., MacArthur J.L., Endres M.W., Davis C., Hofseth L.J., Peña M.M., Vance V.: A novel chemopreventive strategy based on therapeutic microRNAs produced in plants. Cell Res, 2015, 4 (25), 521-524.

[12] Palka-Santini M., Schwarz-Herzke B., Hösel M., Renz D., Auerochs S., Brondke H., Doerfler W.: The gastrointestinal tract as the portal of entry for foreign macromolecules: Fate of DNA and proteins. Mol. Gen. Genomics, 2003, 3 (270), 201-215.

[13] Semenov D.V., Kuligina E.V., Shevyrina O.N., Richter V.A., Vlassov V.V.: Extracellular ribonucleic acids of human milk. Ann. N.Y. Acad. Sci., 2004, 1022, 190-194.

[14] Van Kreel B. K.: The estimation of the apparent standarded free energy change $\Delta \mathrm{G}_{\mathrm{pH}}^{\circ}$ of a biochemical reaction from the standard free energy of formation and apparent free energy of ionization of the participating molecules and its application to the reaction of purine metabolism. Biochem. Educ., 1985, 3 (13), 125-130.

[15] Witwer K.W., Hirschi K.D.: Transfer and functional consequences of dietary microRNAs in vertebrates: Concepts in search of corroboration. Bioessays, 2014, 36, 394-406.

[16] Yu A.-M., Pan Y.-Z.: Noncoding microRNAs: Small RNAs play a big role in regulation of ADME? Acta Pharmaceutica Sinica B, 2012, 2 (2), 93-101. 
[17] Yang J., Hirschi K.D., Farmer L.M.: Dietary RNAs: New stories regarding oral delivery. Nutrients, 2015, 5 (7), 3184-3199.

[18] Yang J., Farmer L.M., Agyekum A.A.A., Hirschi K.D.: Detection of dietary plant-based small RNAs in animals. Cell Res., 2015, 25, 517-520.

[19] Zhang L., Hou D., Chen X., Li1 D., Zhu L., Zhang Y., Li1 J., Bian Z., Liang X., Cai1 X., Yin Y., Wang C., Zhang T., Zhu D., Zhang D., Xu J., Chen O., Ba Y., Liu J., Wang Q., Chen J., Wang J., Wang M., Zhang Q., Zhang J., Zen K., Zhang C.-Y.: Exogenous plant MIR168a specifically targets mammalian LDLRAP1: Evidence of cross-kingdom regulation by microRNA. Cell Res., 2012, 22, 107-126.

[20] Zubay G.F.: Biochemistry. Ed. IV. William C. Brown Publishers, Dubuque, USA, 1998.

\section{ABSORPTION, METABOLISM AND BIOLOGICAL ROLE OF NUCLEIC ACIDS PRESENT IN FOOD}

\section{S u m m a r y}

Nucleic acids are one of the underestimated ingredients in food, especially in the raw or low-processed food products. The paper focuses on discussing conversions in nucleic acids that occur in the human digestive tract, on absorption processes of nucleosides and nucleotides from the gastrointestinal tract; also, the basic steps of their metabolism in the cells of the organism are presented. Digestion products of the nucleic acids are a valuable source of important signalling and precursor molecules. They may also be utilized to form new nucleic acid molecules in the human body. In recent years, low-molecular weight nucleic acids catch most interest, such as non-coding RNA (ncRNA), which are also present in food. It is suggested that the dietary ncRNA can probably impact the regulation of gene expression in the cells of the gastrointestinal tract, and perhaps in other tissues of the consumer. Both the nutritional value and the impact of nucleic acids consumed on the functioning of the genome and transcriptome suggest the need to look into human nutrition in the context of nutrigenomics.

Key words: nucleic acids, food, nutritional properties, nutrigenomics 